\title{
Dictating Selectivity in the Catalytic Vapor-Phase Conversion of Glycerol
}

\author{
Ermelinda Falletta, Michele Rossi and Cristina Della Pina*
}

\author{
Dipartimento di Chimica, Università degli Studi di Milano, via Golgi 19 - 20133 Milano, Italia
}

\begin{abstract}
A viable route for the vapor-phase conversion of glycerol into value-added chemicals is herein presented. This procedure allows to dictate selectivity towards hydroxyacetone (acetol) or methylglyoxal (pyruvaldehyde) by simply tuning the experimental conditions while retaining the same catalytic system. A series of gold- and copper-based catalysts supported on gamma-alumina, including bimetallic formulations, were prepared by incipient wetness impregnation method and tested in a continuous-flow fixed-bed vertical glass reactor at ambient pressure and $\mathrm{T}=250$ $300^{\circ} \mathrm{C}$. The best performance was achieved with $1 \% \mathrm{wt} \mathrm{Au} / \mathrm{Al}_{2} \mathrm{O}_{3}$. Accordingly, the selectivity could be directed to acetol (sel. $72 \%$ ) at $87 \%$ conversion when performing the reaction at $300^{\circ} \mathrm{C}$ and adding $\mathrm{H}_{2}$ to the carrier $\mathrm{N}_{2}$, or towards pyruvaldehyde (sel. $79 \%$ ) at $92 \%$ conversion when adding $\mathrm{O}_{2}$ to $\mathrm{N}_{2}$ at $250^{\circ} \mathrm{C}$. These relatively mild conditions not only allow for energy savings with respect to the common procedures so far reported, but also for catalyst stability that can be easily regenerated after use. Furthermore, the low metal loading in the catalyst ( $1 \% \mathrm{wt})$ and its small amount requested for each test $(0.1 \mathrm{~g}$ catalyst) make this procedure economically sustainable.
\end{abstract}

Keywords: Gold- and copper- based catalysts, Vapor-phase catalysis, Glycerol, Acetol, Pyruvaldehyde.

\section{INTRODUCTION}

The necessity to find eco-friendly routes for replacing petroleum derivatives has prompted both academia and industry to search for potential starting materials in biomass. The biodiesel synthesis is likely the most promising answer to such requests, being a fuel comprised of mono-alkyl ester of long chain fatty acids produced by chemically reacting a vegetable oil or animal fat with an alcohol such as methanol (transesterification reaction) [1, 2]. However the growing overproduction of glycerol, the main byproduct of biodiesel synthesis, has meanwhile introduced another challenge for scientists now called to find effective ways for converting glycerol into valuable chemicals, as propylene glycol, acetol, acrolein and pyruvaldehyde usually obtained from fossil resources [1-11]. The catalytic route employing transition metals (i.e. Au, $\mathrm{Pt}, \mathrm{Pd}, \mathrm{Cu}, \mathrm{Ni}, \mathrm{Ru}$ ) supported on different materials (i.e. $\mathrm{Al}_{2} \mathrm{O}_{3}, \mathrm{SiO}_{2}, \mathrm{TiO}_{2}, \mathrm{C}$ ) in liquid phase seems to meet such expectations, especially for propylene glycol production, but even displays some limits [3-8]. Vapor-phase studies in this field came out later [9-16] but have rapidly gained burgeoning attention since the successful achievement of acrolein by dehydration of glycerol over a variety of catalysts [911]. Less effective is the one-step oxidative dehydration of glycerol employing acrolein as an intermediate, due to the low selectivity towards the

\footnotetext{
"Address correspondence to this author at the Dipartimento di Chimica, Università degli Studi di Milano, via Golgi 19 - 20133 Milano, Italia;

Tel: +39 02 50314408; E-mail: cristina.dellapina@unimi.it
}

corresponding acid. This is because glycerol dehydration to acrolein and its further oxidation to acrylic acid require different catalysts under different reaction conditions. Due to the strategic importance of acrylic acid as a bulk chemical, many efforts are now focused on designing a combined or stacked catalytic system able to perform both the reactions under the same conditions, as well as on optimizing two-step processes [14]. Another key chemical derived from glycerol dehydration is hydroxyacetone (acetol). Acetol is extensively used in food industry to give aroma to foods, as well as in textile industry as a substitute to sodium dithionite usually used as a reducing agent for dyeing processes. Most important, acetol plays a role as an intermediate in organic synthesis because it contains both hydroxyl and carbonyl functional groups [15]. Hence, it is widely employed to promote a variety of reactions including dehydration, hydrogenation, oxidation and polymerization. In particular, propylene glycol via hydrogenation reaction, acrolein through dehydration and methyl glyoxal (pyruvaldehyde) by dehydrogenation. Among these, pyruvaldehyde can serve as an intermediate towards lactic acid. This latter is a high value-added platform molecule in view of its multiple applications, mainly in the production of acrylates and biodegradable/biocompatible polymers [16]. To the best of our knowledge, the selective vaporphase conversion of glycerol to pyruvaldehyde has been so far rarely investigated [17, 18]. A recent study assessed various metals and carriers identifying $5 \% \mathrm{wt}$ $\mathrm{Ag} / \mathrm{Al}_{2} \mathrm{O}_{3}$ as the best catalyst for the oxidehydration of glycerol to pyruvaldehyde optimized at $350^{\circ} \mathrm{C}$ and $\mathrm{O}_{2} /$ glycerol $=0.5$ thus leading to $80 \%$ yield. The 
authors also demonstrated the superiority of pyruvaldehyde, compared to dihydroxyacetone (DHA), as the intermediate in an alternative two-step glycerolto-lactic acid process [18].

In this short communication, we introduce our preliminary results on the possibility to dictate selectivity towards acetol or pyruvaldehyde by vaporphase conversion of glycerol over the same catalyst (1\%wt $\mathrm{Au} / \mathrm{Al}_{2} \mathrm{O}_{3}$ ) by simply tuning temperature, $\mathrm{N}_{2} / \mathrm{H}_{2} / \mathrm{O}_{2}$ ratios and gas flow rate thereof. Notably, pyruvaldehyde could be achieved with $79 \%$ selectivity at $92 \%$ conversion when conducting the reaction at $250^{\circ} \mathrm{C}$ and adding dioxygen to dinitrogen. The mild experimental conditions, the low metal loading in the catalyst and its small amount required for the tests offer a sustainable route for the glycerol valorisation to value-added chemicals.

\section{EXPERIMENTAL}

\section{Catalysts Preparation and Characterization}

A series of monometallic gold and copper catalysts supported on $\gamma$-alumina was prepared by incipient wetness impregnation. Different bimetallic $\mathrm{Au}-\mathrm{Cu}$ formulations were also synthesized for comparison.

Gold supported on $\gamma$-alumina catalysts $(0.5,1$ and $2.5 \mathrm{wt} \% \mathrm{Au}$ nominal loading, $\gamma-\mathrm{Al}_{2} \mathrm{O}_{3}$ from BASF, D10-10, particle size $0.4-0.8 \mathrm{~mm}, A_{s}=264 \mathrm{~m}^{2} / \mathrm{g}$, $\mathrm{V}_{\mathrm{p}}=0.59 \mathrm{~mL} / \mathrm{g}$ ) were prepared using the incipient wetness method. Gold precursor $\left(\mathrm{HAuCl}_{4}\right.$ aqueous solution, $50 \mathrm{mg} / \mathrm{mL}$ of $\mathrm{Au}$ ), was prepared dissolving $\mathrm{Au}$ of 99.9999 in sponge from Fluka in aqua regia and diluted to the appropriate volume with ultrapure deionized water MilliQ ${ }^{\circledR}$. After thermal pre-treatment of alumina at $300^{\circ} \mathrm{C}$ in air flow $(20 \mathrm{ml} / \mathrm{min})$ for $2 \mathrm{~h}$, determined aliquots of chloroauric acid solution $(0.10$, 0.20 or $0.50 \mathrm{~mL}$ according to 0.5 , 1 or $2.5 \mathrm{wt} \%$ gold loading respectively) were impregnated onto $1 \mathrm{~g}$ of $\gamma-\mathrm{Al}_{2} \mathrm{O}_{3}$ while mixing with a glass rod for $10 \mathrm{~min}$. The resulting powder was then contacted with a freshly prepared aqueous solution of sodium borohydride to reduce $\mathrm{Au}^{3+}$ to $\mathrm{Au}\left(\mathrm{NaBH}_{4} 99.0 \%\right.$ purity from Aldrich, $0.1 \mathrm{M} \mathrm{NaBH}_{4}$ aqueous solution) with $\mathrm{Au}: \mathrm{NaBH}_{4}$ weight ratio $=1$. The suspension was kept on stirring at room temperature for $10 \mathrm{~min}$. Due to the reported detrimental effect of chloride to obtaining small and active gold nanoparticles [19], the solid product was thoroughly washed with water until washings contained no chloride. Thereafter, the catalyst was dried in oven at $120^{\circ} \mathrm{C}$ for $1 \mathrm{~h}$. Copper supported on $\gamma$-alumina catalyst (1\%wt nominal loading $\mathrm{Cu} / \mathrm{Al}_{2} \mathrm{O}_{3}$ ) was prepared following the same incipient wetness impregnation procedure but with some differences. Copper precursor $\left(\mathrm{Cu}\left(\mathrm{NO}_{3}\right)_{2} \cdot 3 \mathrm{H}_{2} \mathrm{O}\right.$ from Sigma-Aldrich, 98-103\%) was dissolved in water to achieve a $20 \mathrm{mg} / \mathrm{mL}$ aqueous solution. After impregnation of $0.50 \mathrm{~mL}$ copper solution onto $1 \mathrm{~g} \gamma-\mathrm{Al}_{2} \mathrm{O}_{3}, 0.8 \mathrm{~mL}$ of ammonia aqueous solution (30\% $\mathrm{NH}_{3}$ from Sigma-Aldrich) was contacted with the powder and stirred for $10 \mathrm{~min}$ long. Copper reduction was then performed by $\mathrm{H}_{2}(99.99 \%$ from SIAD, 5 $\mathrm{mL} / \mathrm{min}$ ) at $350^{\circ} \mathrm{C}$ for $1 \mathrm{~h}$ directly on the continuous-flow fixed-bed reactor used for the catalytic tests. Bimetallic catalysts with two different $\mathrm{Au}-\mathrm{Cu}$ molar ratios (1:1 and 1:4) were prepared as above. Mixtures of $\mathrm{HAuCl}_{4}$ and $\mathrm{Cu}\left(\mathrm{NO}_{3}\right)_{2}$ aqueous solutions were used as metal precursors of the catalysts with a nominal total metal loading of $1 \%$ wt on $\gamma$-alumina. The metal content in the catalysts was confirmed by inductively coupled plasma analyses (ICP), while $\mathrm{N}_{2}$-adsorption was conducted at $-196^{\circ} \mathrm{C}$ (Brunauer-Emmett-Teller method or BET) using a Micromeritics Tristar analyser for determining the specific surface area of selected samples. X-ray powdered diffraction (XRPD) was performed using a Rigaku Miniflex 600 diffractometer with $\mathrm{Cu} \mathrm{Ka}$ radiation $(\lambda=0.1541 \mathrm{~nm})$, acquiring data in the $5-80^{\circ} 2 \theta$ range with a step size of $0.05^{\circ}$ and a counting time of $8 \mathrm{~s}$ per step.

TEM images were acquired using a $\mathrm{FEl}$ Talos instrument operated at $200 \mathrm{kV}$. Powdered sample was deposited on Mo-grids as such.

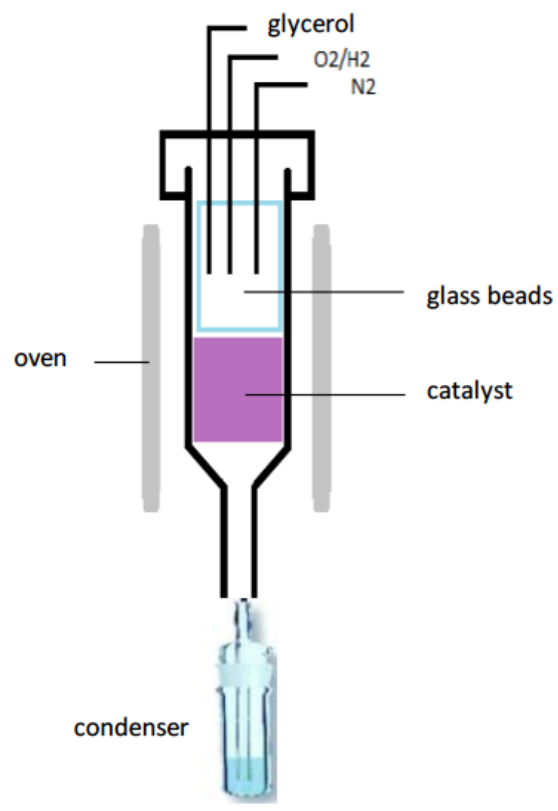

Scheme 1: Continuous-flow fixed-bed vertical glass reactor setup. 


\section{Catalytic Tests}

The oxidehydration of glycerol to pyruvaldehyde via acetol was carried out at ambient pressure in a continuous-flow fixed-bed vertical glass reactor $(\mathrm{h}=$ $250 \mathrm{~mm}, \mathrm{~d}=12 \mathrm{~mm}$ ), fitted with a glass frit carrying the catalyst $(0.1 \mathrm{~g})$ and provided with an electronically controlled furnace. Glass beads (2-mm size) were loaded in order to facilitate the evaporation of the liquid feed (Scheme 1).

Prior to the measurements, the catalysts were evacuated at $300^{\circ} \mathrm{C}$ for $1 \mathrm{~h}$. Pure glycerol (from Sigma Aldrich, 99\%) was supplied through a syringe pump $\left(1 \mathrm{~mL} / \mathrm{h}\right.$ ). The gaseous stream of $\mathrm{N}_{2} / \mathrm{H}_{2}$ (conversion to acetol) or $\mathrm{N}_{2} / \mathrm{O}_{2}$ (conversion to pyruvaldehyde) with 20 to $100 \mathrm{NmL} \min ^{-1}$ was controlled by a mass flow instrument (all the gases were supplied by SIAD, $99.999 \%$ ). Liquid vaporisation occurred on the reactor wall prior to the catalytic bed. The tests were performed at different temperatures in the range $250-300{ }^{\circ} \mathrm{C}$ : below $250{ }^{\circ} \mathrm{C}$ scarce glycerol conversion occurred, whereas above $300^{\circ} \mathrm{C}$ selectivity towards the desired products progressively decreased. The system was heated at the reaction temperature in $\mathrm{N}_{2}$ flow and allowed to equilibrate for $1 \mathrm{~h}$. Afterwards, the proper $\mathrm{N}_{2} / \mathrm{H}_{2}$ flow (typically, $18 \mathrm{~mL} / \mathrm{min} \mathrm{N}_{2}$ and $2 \mathrm{~mL} / \mathrm{min}_{2}$ ) or $\mathrm{N}_{2} / \mathrm{O}_{2}$ flow (namely, 10 to $80 \mathrm{~mL} / \mathrm{min} \mathrm{N}_{2}$ and 10 to 20 $\mathrm{mL} / \mathrm{min} \mathrm{O}_{2}$ ) was admitted along with glycerol. The condensable reaction products were periodically collected by bubbling the effluent into a cold trap $\left(0^{\circ} \mathrm{C}\right)$ containing $0.01 \mathrm{M} \mathrm{H}_{3} \mathrm{PO}_{4}$ as the solvent and then analyzed by high-performance liquid chromatography (HPLC system from Shimadzu equipped with LC-10AD pump, RID-10A refractive index detector and using a Metacarb $87 \mathrm{H}$ column with phosphoric acid at $0.6 \mathrm{~mL} \mathrm{~min}^{-1}$ as the eluent). The conversion of glycerol (Conv\%) and selectivity to the product (Sel $\mathrm{prod}_{\mathrm{p}} \%$ ) were calculated as follows:

$$
\begin{aligned}
\text { Conv } \% & =1-\frac{C_{g l y}}{C_{g l y}^{0}} * 100 \\
S e l_{\text {prod }} \% & =\frac{C_{\text {prod }}}{C_{\text {gly }}^{0}-C_{\text {gly }}} * 100
\end{aligned}
$$

where $\mathrm{C}$ refers to the outlet concentration of glycerol or product and $\mathrm{C}_{\text {gly }}^{0}$ refers to the inlet concentration of glycerol. The average experimental error after three repetitions of the same catalytic run was within $5 \%$. Blank tests conducted with only the glass beads loaded into the reactor or $\gamma-\mathrm{Al}_{2} \mathrm{O}_{3}$ led to zero glycerol conversion or negligible selectivity to the desired products respectively.

\section{RESULTS AND DISCUSSION}

A series of alumina-supported metal catalysts was prepared $\left(0.5-2.5 \%\right.$ wt $\mathrm{Au} / \mathrm{Al}_{2} \mathrm{O}_{3}, 1 \%$ wt $\mathrm{Cu} / \mathrm{Al}_{2} \mathrm{O}_{3}, 1 \%$ wt Au-Cu $(1: 1) / \mathrm{Al}_{2} \mathrm{O}_{3}$ and $1 \%$ wt Au-Cu $\left.(1: 4) / \mathrm{Al}_{2} \mathrm{O}_{3}\right)$, as aforementioned, to assess the role of the metal and their bimetallic formulations in the selective vaporphase conversion of glycerol to acetol and pyruvaldehyde. The metals comprised gold and copper, selected on the basis of their reported catalytic activity in the dehydrogenation of alcohols, whereas the presence of alumina as the supporting material seems to promote their dehydration [18]. The experimental conditions were properly set up to boost conversion while dictating selectivity towards acetol or pyruvaldehyde (Scheme 2).

\section{Dehydration to Acetol}

In principle, glycerol dehydration can lead to two products, acetol and 3-hydroxypropanal (Scheme 3).

The aldehyde is thermodynamically favored, due to the stable secondary carbocation formation, but kinetically hindered. Hence, acetol is the expected

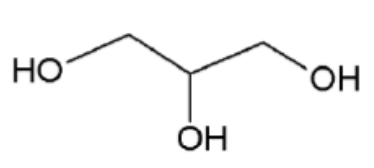

glycerol

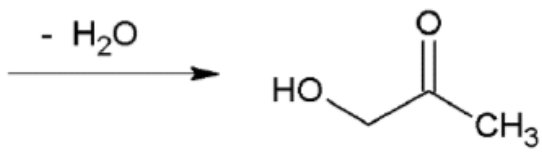

acetol

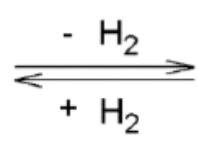

pyruvaldehyde

Scheme 2: Glycerol conversion to acetol (dehydration step) and/or to pyruvaldehyde (dehydrogenation step). 
<smiles>OCC(O)CO</smiles>

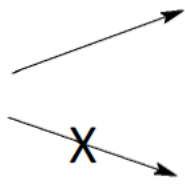

glycerol

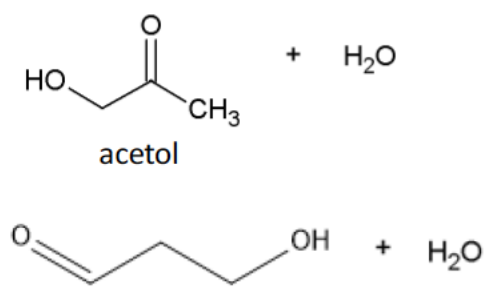

3-hydroxypropanal

Scheme 3: Glycerol dehydration pathway.

dehydration product under these conditions. A first preliminary test over $1 \% \mathrm{wt} \quad \mathrm{Au} / \mathrm{Al}_{2} \mathrm{O}_{3}(0.1 \mathrm{~g})$ was performed at $250^{\circ} \mathrm{C}$, under $\mathrm{N}_{2}$ flow $\left(20 \mathrm{~mL} \mathrm{~min}^{-1}\right)$ and 1 $\mathrm{mL} \mathrm{h} \mathrm{h}^{-1}$ glycerol. The low temperature prevented from reaching adequate conversion (only 26\%) but, interestingly, selectivity to pyruvaldehyde (65\%) prevailed over acetol (34\%). In order to address the selectivity to acetol, $\mathrm{H}_{2}\left(2 \mathrm{~mL} \mathrm{~min}^{-1}\right)$ was added to $\mathrm{N}_{2}$ $\left(18 \mathrm{~mL} \mathrm{~min}{ }^{-1}\right)$. As evinced from Scheme 2, dihydrogen can shift the acetol/pyruvaldehyde equilibrium direction towards acetol. Actually the results confirmed the forecast just at $250^{\circ} \mathrm{C}$, but a further beneficial effect in terms of conversion and selectivity to acetol was registered at higher temperatures (Table 1). Worth noting, $71.8 \%$ selectivity to acetol at $87.0 \%$ conversion was yielded at $300^{\circ} \mathrm{C}$, together with $12.0 \%$ pyruvaldehyde and $16.2 \%$ of acrolein, acetic acid and glycerol oligomers.
To assess the effect of gold loading, the tests were repeated over $0.5 \%$ and $2.5 \%$ wt $A u / \mathrm{Al}_{2} \mathrm{O}_{3}$ catalysts. The results are summarized in Tables $\mathbf{2}$ and $\mathbf{3}$.

Comparing the catalysts performance at $300^{\circ} \mathrm{C}$, conversion was always above $85 \%$ but selectivity to acetol decreased to $64.8 \%$ over $0.5 \%$ wt $\mathrm{Au} / \mathrm{Al}_{2} \mathrm{O}_{3}$ and to $46.2 \%$ over the highest metal loading catalyst. Consequently, $1 \% \mathrm{wt} \quad \mathrm{Au} / \mathrm{Al}_{2} \mathrm{O}_{3}$ was taken as the catalyst of choice for further assessment, including a comparison with the copper catalyst $\left(1 \%\right.$ wt $\left.\mathrm{Cu} / \mathrm{Al}_{2} \mathrm{O}_{3}\right)$ (Table 4) and thereof bimetallic formulations, 1\%wt Au$\mathrm{Cu}(1: 1) / \mathrm{Al}_{2} \mathrm{O}_{3}$ and $1 \%$ wt Au-Cu (1:4)/Al $\mathrm{O}_{3}$.

Lower selectivity to acetol (51.5\%) at lower conversion $(80.7 \%)$ was achieved over $1 \%$ wt $\mathrm{Cu} / \mathrm{Al}_{2} \mathrm{O}_{3}$ with respect to the gold catalyst at the same metal loading and temperature $\left(300^{\circ} \mathrm{C}\right)$, as evinced by comparing Tables $\mathbf{1}$ and $\mathbf{4}$. Alloying gold with a second

Table 1: Glycerol Dehydration and Product Selectivity over $1 \%$ wt $A u / A I_{2} \mathrm{O}_{3}$ as a Function of Temperature. Reaction Conditions: $P=1$ bar, Catalyst $=0.1 \mathrm{~g}$, Glycerol $=1 \mathrm{~mL} \mathrm{~h}^{-1}, \mathrm{~N}_{2}=18 \mathrm{~mL} \mathrm{~min}{ }^{-1}, \mathrm{H}_{2}=2 \mathrm{~mL} \mathrm{~min}^{-1}$. 'Others' Refers to Acrolein, Acetic Acid, Glycerol Oligomers

\begin{tabular}{|c|c|c|c|c|}
\hline $\mathbf{T}\left[{ }^{\circ} \mathbf{C}\right]$ & Conversion $\%$ & Selectivity to Pyruvaldehyde $\%$ & Selectivity to Acetol \% & Others \% \\
\hline \hline 250 & 30.2 & 31.4 & 52.4 & 27.2 \\
\hline 270 & 57.1 & 25.1 & 57.1 & 22.7 \\
\hline 280 & 67.0 & 21.7 & 71.8 & 21.2 \\
\hline 300 & 87.0 & 12.0 & 16.2 \\
\hline
\end{tabular}

Table 2: Glycerol Dehydration and Product Selectivity over $0.5 \%$ wt $A u / A_{2} \mathrm{O}_{3}$ as a Function of Temperature. Reaction Conditions: $P=1$ bar, Catalyst $=0.1 \mathrm{~g}$, Glycerol $=1 \mathrm{~mL} \mathrm{~h}^{-1}, \mathrm{~N}_{2}=18 \mathrm{~mL} \mathrm{~min}^{-1}, \mathrm{H}_{2}=2 \mathrm{~mL} \mathrm{~min}^{-1}$. 'Others' Refers to Acrolein, Acetic Acid, Glycerol Oligomers

\begin{tabular}{|c|c|c|c|c|}
\hline $\mathbf{T}\left[{ }^{\circ} \mathbf{C}\right]$ & Conversion \% & Selectivity to Pyruvaldehyde \% & Selectivity to Acetol \% & 37.0 \\
\hline \hline 250 & 31.5 & 32.4 & 39.5 & 35.9 \\
\hline 270 & 55.1 & 28.6 & 52.8 & 34.0 \\
\hline 280 & 67.5 & 19.9 & 64.8 & 31.9 \\
\hline 300 & 85.4 & 14.0 & 28.1 \\
\hline
\end{tabular}


Table 3: Glycerol Dehydration and Product Selectivity over 2.5\%wt $\mathrm{Au}_{\mathrm{Al}} \mathrm{Al}_{2} \mathrm{O}_{3}$ as a Function of Temperature. Reaction Conditions: $P=1 \mathrm{bar}$, Catalyst $=0.1 \mathrm{~g}$, Glycerol $=1 \mathrm{~mL} \mathrm{~h}^{-1}, \mathrm{~N}_{2}=18 \mathrm{~mL} \mathrm{~min}^{-1}, \mathrm{H}_{2}=2 \mathrm{~mL} \mathrm{~min}^{-1}$. 'Others' Refers to Acrolein, Acetic Acid, Glycerol Oligomers

\begin{tabular}{|c|c|c|c|c|}
\hline $\mathbf{T}\left[{ }^{\circ} \mathbf{C}\right.$ ] & Conversion \% & Selectivity to Pyruvaldehyde \% & Selectivity to Acetol \% & Others \% \\
\hline \hline 250 & 36.8 & 33.7 & 40.2 & 16.1 \\
\hline 270 & 56.3 & 41.4 & 49.4 & 18.3 \\
\hline 280 & 61.7 & 36.1 & 46.2 & 17.1 \\
\hline 300 & 88.3 & 36.7 & & 4.5 \\
\hline
\end{tabular}

Table 4: Glycerol Dehydration and Product Selectivity over $1 \%$ wt $\mathrm{Cu} / \mathrm{Al}_{2} \mathrm{O}_{3}$ as a Function of Temperature. Reaction Conditions: $P=1$ bar, Catalyst $=0.1 \mathrm{~g}$, Glycerol $=1 \mathrm{~mL} \mathrm{~h}^{-1}, \mathrm{~N}_{2}=18 \mathrm{~mL} \mathrm{~min}^{-1}, \mathrm{H}_{2}=2 \mathrm{~mL} \mathrm{~min}^{-1}$. 'Others' Refers to Acrolein, Acetic Acid, Glycerol Oligomers

\begin{tabular}{|c|c|c|c|c|}
\hline $\mathbf{T}\left[{ }^{\circ} \mathbf{C}\right]$ & Conversion \% & Selectivity to Pyruvaldehyde \% & Selectivity to Acetol \% & Others \% \\
\hline \hline 250 & 36.8 & 44.9 & 40.1 & 15.0 \\
\hline 270 & 49.7 & 41.7 & 44.0 & 21.6 \\
\hline 280 & 73.8 & 34.4 & 51.5 & 32.7 \\
\hline 300 & 80.7 & 15.8 & 16.6 & \\
\hline
\end{tabular}

metal (i.e. $\mathrm{Cu}$ and $\mathrm{Pt}$ ) has been demonstrated to enhance gold catalytic performance, especially in the selective oxidation of alcohols and aldehydes [20-22]. Moreover, the possibility to decrease gold amount by adding a cheaper metal as copper could be welcome in view of a potential industrial application. Due to our expertise in gold-based bimetallic catalysts, we decided to explore two gold-copper formulations, $1 \% \mathrm{wt} \mathrm{Au}-\mathrm{Cu}$ (1:1)/ $/ \mathrm{Al}_{2} \mathrm{O}_{3}$ and $1 \%$ wt Au-Cu (1:4)/Al $\mathrm{O}_{3}$ under the same experimental conditions. Differently from our previous experience, no marked benefit in using bimetallic catalysts was detected and monometallic gold was confirmed to be superior especially in terms of selectivity to acetol. To better visualize the performance at $300^{\circ} \mathrm{C}$ of all the catalysts, a series of histograms is reported in Figure 1.

Regarding the two bimetallic formulations, $1 \%$ wt Au$\mathrm{Cu}(1: 1) / \mathrm{Al}_{2} \mathrm{O}_{3}$ allowed to direct selectivity more to the desired acetol than to a mixture of other dehydration/oxidation/oligomerization products (namely acrolein, acetic acid and glycerol oligomers). Conversely, increasing copper with respect to gold led to a selectivity dispersion in line with what observed employing copper monometallic catalyst (Figure 1 BD). The reasons might be multiple. Copper and gold exhibit two different redox potentials $\left(\mathrm{E}^{\circ} \mathrm{Au}^{+}+\mathrm{e}^{-} \rightarrow \mathrm{Au}=\right.$ $1.69 \mathrm{~V}$ and $\mathrm{E}^{\circ} \mathrm{Cu}^{2+}+2 \mathrm{e}-\rightarrow \mathrm{Cu}=0.34 \mathrm{~V}$ ) which also impact differently on their catalytic activity and stability.
Copper, in fact, can be more easily oxidized than gold to such an extent that its initial zero oxidation state might not be retained before starting the catalytic tests. Another key point is the role of the supporting material, $\gamma-\mathrm{Al}_{2} \mathrm{O}_{3}$. The choice of alumina was suggested by literature reports indicating that glycerol dehydration to acetol is favored by Lewis-acid sites [18]. In principle, the impregnation of the support with metal precursors could alter its Lewis and Brønsted acidity. Regarding this latter, the potential replacement of protons at ionexchange positions with the metal cations might change Brønsted acidity. Accordingly, the different electronegativity of the metals could slightly alter the acidic nature of $\mathrm{H}$ atoms of hydroxyl groups. Such hypotheses should be underpinned by advanced analytical characterization, which is beyond the scope of a brief research communication but planned for a future assessment study. As far as basic characterization is concerned, XRPD diffractograms were collected over the monometallic catalysts (Au and $\mathrm{Cu}$ ) and the best bimetallic formulation in terms of selectivity $(\mathrm{Au}: \mathrm{Cu}=1: 1)$, before and after the dehydration reaction at $300^{\circ} \mathrm{C}$ (Figure 2 A-C). The supporting material $\gamma-\mathrm{Al}_{2} \mathrm{O}_{3}$ as such was always included for comparison. The crystalline phases were identified by comparing the diffraction patterns with those present in ICDD database (International Centre for Diffraction Data, www.icdd.com). The diffraction patterns of $\mathrm{Y}-\mathrm{Al}_{2} \mathrm{O}_{3}$ display three major peaks at $2 \theta$ 

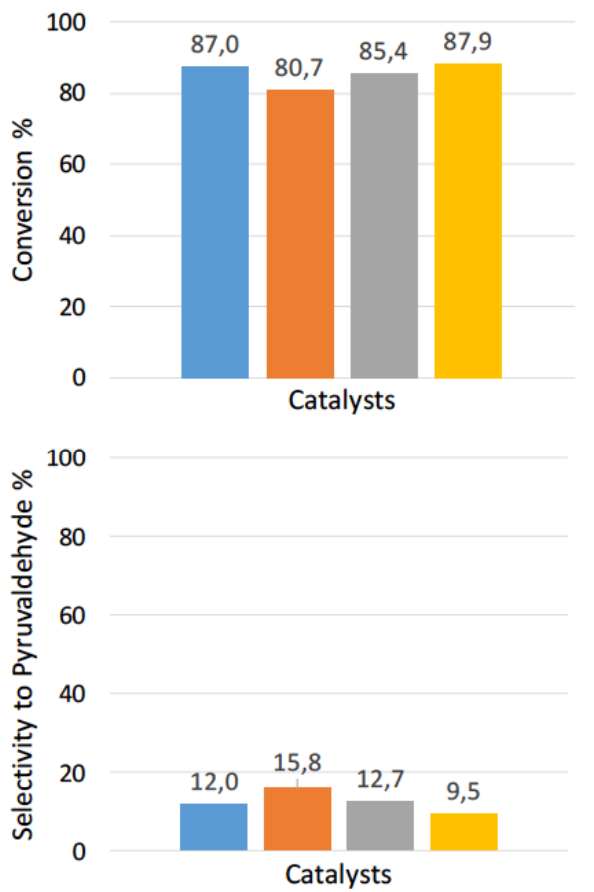

A

1\%Au/Al 203

- 1\%Cu/Al2O3

- 1\%Au-Cu(1:1)/Al2O3

- 1\%Au-Cu(1:4)/Al2O3

B

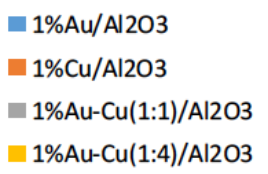

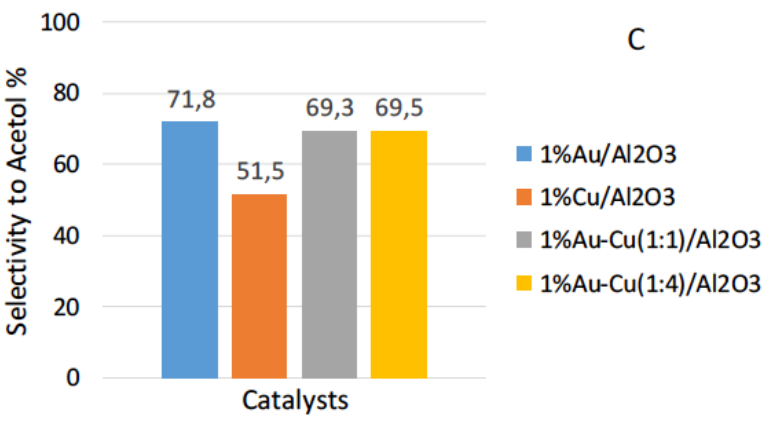

100

80

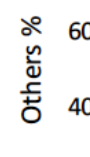

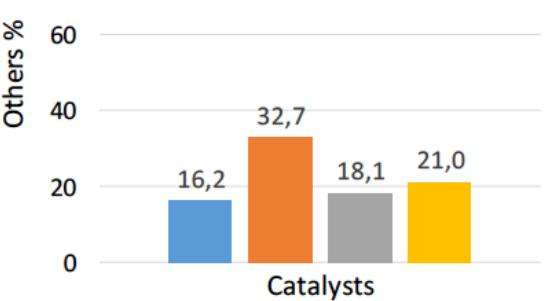

D

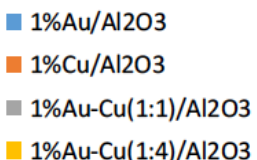

- 1\%Au/Al2O3

1\%Au-Cu(1:1)/Al2O3

1\%Au-Cu(1:4)/Al2O3

Figure 1: Comparison among the catalysts in the glycerol dehydration at $300^{\circ} \mathrm{C}$ over $1 \%$ wt $\mathrm{Au} / \mathrm{Al}_{2} \mathrm{O}_{3}, 1 \% \mathrm{wt} \mathrm{Cu} / \mathrm{Al}_{2} \mathrm{O}_{3}, 1 \%$ wt $\mathrm{Au}-$ $\mathrm{Cu}(1: 1) / \mathrm{Al}_{2} \mathrm{O}_{3}$ and $1 \%$ wt Au-Cu (1:4)/Al $\mathrm{O}_{3}$ catalysts. A) conversion (\%); B) selectivity to pyruvaldehyde (\%); C) selectivity to acetol (\%) D) Others (\%) refers to acrolein, acetic acid, glycerol oligomers. Reaction conditions: $T=300^{\circ} \mathrm{C}, P=1 \mathrm{bar}$, catalyst $=$ $0.1 \mathrm{~g}$, glycerol $=1 \mathrm{~mL} \mathrm{~h}^{-1}, \mathrm{~N}_{2}=18 \mathrm{~mL} \mathrm{~min}^{-1}, \mathrm{H}_{2}=2 \mathrm{~mL} \mathrm{~min}^{-1}$.

equal to $37.1^{\circ}, 45.9^{\circ}$ and $67.0^{\circ}$ (Figure 2 A-C). These correspond to reflections of $\mathrm{Y}-\mathrm{Al}_{2} \mathrm{O}_{3}$ crystal planes (311), (400) and (440), respectively. No peaks for $\mathrm{Cu}$ diffraction or cupric oxide were observed in $1 \%$ $\mathrm{Cu} / \mathrm{Al}_{2} \mathrm{O}_{3}$ either before or after use, thus suggesting that the metal was in amorphous state or maybe highly dispersed on support (Figure 2B). Regarding gold, its nanocrystals present four distinct peaks at $2 \theta=38.1^{\circ}$, $44.3^{\circ}, 64.5^{\circ}$ and $77.7^{\circ}$ corresponding to standard Bragg reflection (111), (200), (220) and (311) of face centered cubic lattice. Despite alumina major peaks overlapping, the first three peaks of gold are able to emerge in $1 \% \mathrm{Au} / \mathrm{Al}_{2} \mathrm{O}_{3}$ catalyst (Figure 2A). The fourth typical peak at $2 \theta=77.7^{\circ}$ is particularly evident since alumina presents no reflection in this area. After use, some gold peaks (namely at $2 \theta=38.1^{\circ}$ and $77.7^{\circ}$ ) look slightly sharper than in the 'fresh' catalyst likely due to nanoparticle size growth as confirmed by TEM image (see later on, Figure 4). The bimetallic catalyst displays distinctly the first and fourth peaks of gold at $2 \theta=38.1^{\circ}$ and $77.7^{\circ}$, whereas the intermediate ones $\left(44.3^{\circ}\right.$ and $64.5^{\circ}$ ) are not detectable as well as copper peaks.

The specific surface area of the supporting material $\mathrm{Y}-\mathrm{Al}_{2} \mathrm{O}_{3}$ is in line with the typical value reported in literature for gamma alumina $\left(A_{s}=264 \mathrm{~m}^{2} / \mathrm{g}\right.$ by $B E T$ method). The metal impregnation led to only minor modification in the surface area of all the samples, thus suggesting a good metal dispersion in particular in the case of gold, alone or alloyed with copper (Table 5).

Table 5: Specific Surface area Determined by $\mathrm{N}_{2}-$ Adsorption at $-196^{\circ} \mathrm{C}$ (Brunauer-Emmett-Teller Method) over $\mathrm{Y}-\mathrm{Al}_{2} \mathrm{O}_{3}$ and the Catalysts asPrepared (1\%wt $\mathrm{Au} / \mathrm{Al}_{2} \mathrm{O}_{3} ; 1 \%$ wt $\mathrm{Cu} / \mathrm{Al}_{2} \mathrm{O}_{3}$ and $1 \%$ wt Au-Cu (1:1)/AI $\left.\mathrm{O}_{3}\right)$

\begin{tabular}{|c|c|}
\hline Sample & $\mathbf{A}_{\mathbf{s}}\left(\mathbf{m}^{2} / \mathbf{g}\right)$ \\
\hline \hline $\mathrm{Y}-\mathrm{Al}_{2} \mathrm{O}_{3}$ & 264 \\
\hline $1 \% \mathrm{Au} / \mathrm{Al}_{2} \mathrm{O}_{3}$ & 226 \\
\hline $1 \% \mathrm{Cu} / \mathrm{Al}_{2} \mathrm{O}_{3}$ & 216 \\
\hline $1 \% \mathrm{Au}-\mathrm{Cu}(1: 1) / \mathrm{Al}_{2} \mathrm{O}_{3}$ & 227 \\
\hline
\end{tabular}

Since $1 \% \mathrm{wt} A u / \mathrm{Al}_{2} \mathrm{O}_{3}$ emerged as the catalyst with the best overall performance in glycerol conversion to acetol, it was selected to carry out even the second step towards pyruvaldehyde.

\section{Dehydrogenation to Pyruvaldehyde}

A key product derived from glycerol dehydration and subsequent dehydrogenation of acetol is pyruvaldehyde. As a strategy to shift the acetol/pyruvaldehyde equilibrium towards the 

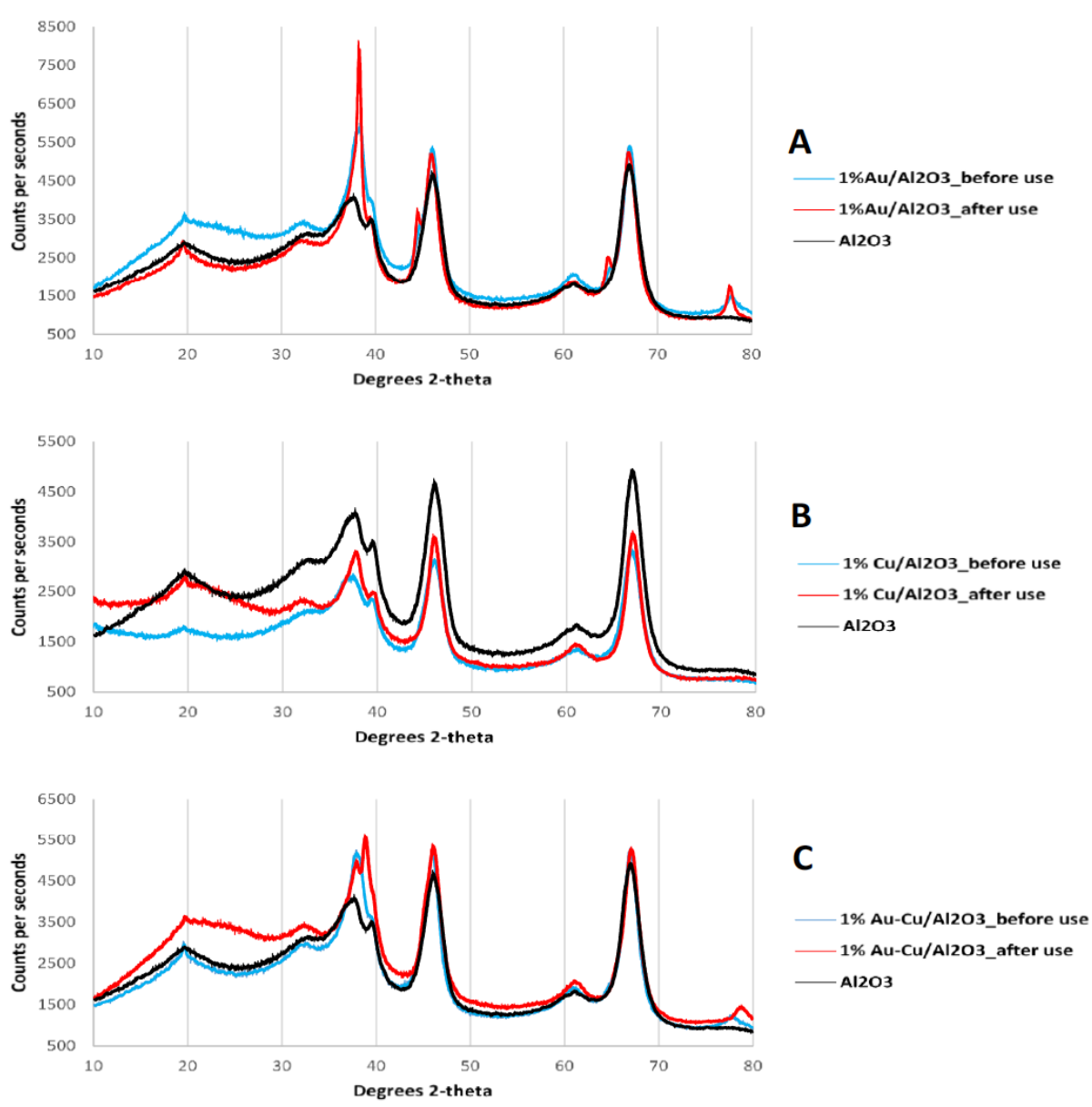

Figure 2: XRPD patterns before and after glycerol dehydration at $300^{\circ} \mathrm{C}$ over: A) $1 \%$ wt $\left.A u / \mathrm{Al}_{2} \mathrm{O}_{3} ; \mathbf{B}\right) 1 \%$ wt $\mathrm{Cu} / \mathrm{Al}_{2} \mathrm{O}_{3}$ and C) $1 \%$ wt Au-Cu (1:1)/Al $\mathrm{O}_{3}$. The supporting material $\gamma-\mathrm{Al}_{2} \mathrm{O}_{3}$ is always included for comparison.

aldehyde, dioxygen was added to the carrier dinitrogen. Accordingly, the formation of $\mathrm{H}_{2} \mathrm{O}$ from the reaction between $\mathrm{O}_{2}$ and the withdrawn $\mathrm{H}_{2}$ is supposed to push the equilibrium to the right (Scheme 4).

In order to confirm such hypothesis, $1 \%$ wt $\mathrm{Au} / \mathrm{Al}_{2} \mathrm{O}_{3}$ $(0.1 \mathrm{~g})$ was tested in the oxidehydration of glycerol at $250^{\circ} \mathrm{C}$, glycerol $1 \mathrm{~mL} \mathrm{~h}^{-1}$ and tuning $\mathrm{O}_{2}$ /glycerol molar ratio (around 0.5-4) as well as the total gaseous flow $\left(\mathrm{N}_{2}+\mathrm{O}_{2}\right.$, from 20 to $\left.100 \mathrm{~mL} \mathrm{~min}^{-1}\right)$. The best performance was registered with a $\mathrm{O}_{2} /$ glycerol molar ratio around 4 , that is markedly higher than the stoichiometric one, at total gaseous flow of $70 \mathrm{~mL}$ $\mathrm{min}^{-1}$. Under these conditions, $78.8 \%$ selectivity to pyruvaldehyde and $12.5 \%$ to acetol at $91.8 \%$ conversion was yielded. Notably, this was achieved at a lower temperature $\left(250^{\circ} \mathrm{C}\right)$ and catalyst amount with respect to the presently reported ones [18].

As it is crucial that catalysts can be re-used over many reaction cycles, the stability of $1 \% \mathrm{wt} A u / \mathrm{Al}_{2} \mathrm{O}_{3}$ was evaluated at the optimal experimental conditions in a 9h-run (Figure 3).<smiles>OCC(O)CO</smiles>

glycerol<smiles>CC(=O)CO</smiles>

acetol

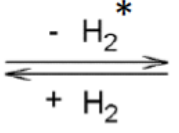

pyruvaldehyde<smiles>CC(=O)C=O</smiles>

$$
* \mathrm{H}_{2}+1 / 2 \mathrm{O}_{2} \longrightarrow \mathrm{H}_{2} \mathrm{O}
$$

Scheme 4: Oxidehydration of glycerol to pyruvaldehyde. 

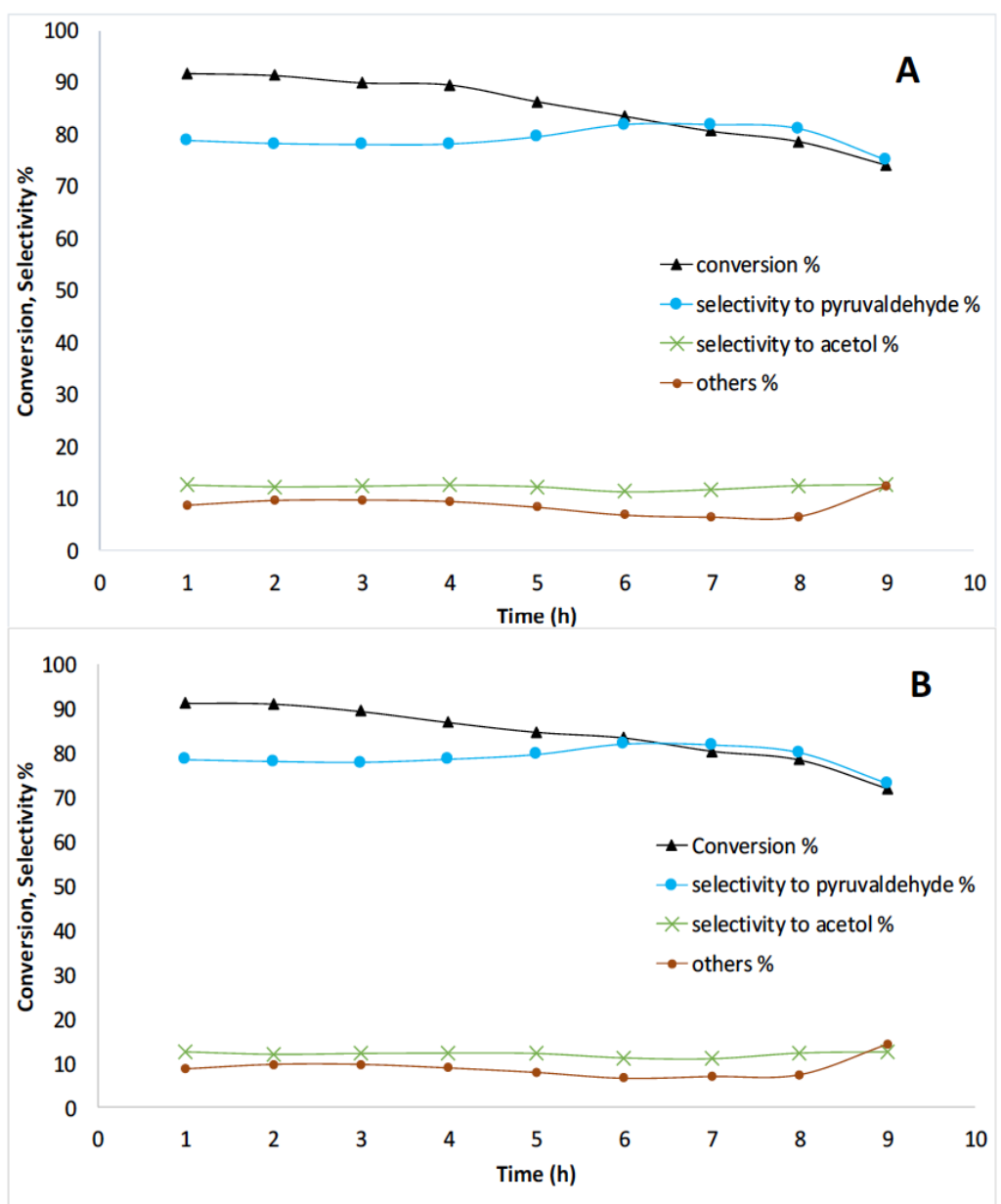

Figure 3: Conversion and product selectivity as a function of the time-on-stream in glycerol oxidehydration over $1 \%$ wt $\mathrm{Au} / \mathrm{Al}_{2} \mathrm{O}_{3}$ during: A) the first 9h-run; $\mathrm{B}$ ) the second 9h-run after catalyst regeneration. Reaction conditions: $T=250^{\circ} \mathrm{C}, P=1 \mathrm{bar}, \mathrm{catalyst}=$ $0.1 \mathrm{~g}$, glycerol $=1 \mathrm{~mL} \mathrm{~h}^{-1}, \mathrm{~N}_{2}=50 \mathrm{~mL} \mathrm{~min}^{-1}, \mathrm{O}_{2}=20 \mathrm{~mL} \mathrm{~min}^{-1}$. Others (\%) refers to acrolein, acetic acid, glycerol oligomers.

Over the first 9h-run, both conversion and selectivity to pyruvaldehyde retained their initial high values for 4 $\mathrm{h}$ long, afterwards conversion slightly decreased whereas selectivity moderately increased up to $8 \mathrm{~h}$. During the last hour, a drop in pyruvaldehyde selectivity was detected, together with an increase in acrolein, acetic acid and glycerol oligomers. This minor loss of conversion could be ascribed to the deposition of carbonaceous species and/or sintering of gold. TEM micrographs of the catalyst before and after the $9 \mathrm{~h}-$ lifetime test highlighted the robustness of the material since only a negligible sintering could be observed. The average nanoparticles diameter slightly changed from 3.1 to $4.7 \mathrm{~nm}$ (Figure 4 A, B).

More likely the catalyst underwent a slight fouling. To confirm this, $1 \%$ wt $\mathrm{Au} / \mathrm{Al}_{2} \mathrm{O}_{3}$ was regenerated by keeping it in the flow fixed-bed reactor under dioxygen

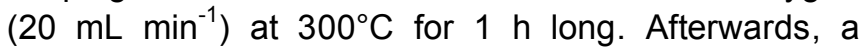
second catalytic cycle was repeated under the same experimental conditions. Actually, the initial catalytic performance was restored and maintained over the second 9h-run similarly as the first run (Figure 3B).

\section{CONCLUSIONS}

In this short communication, we have presented our preliminary study aiming to dictate selectivity towards acetol or pyruvaldehyde by vapor-phase oxidehydrogenation of glycerol over the same catalyst by simply tuning temperature, $\mathrm{N}_{2} / \mathrm{H}_{2} / \mathrm{O}_{2}$ ratios and gas flow rate thereof. A series of mono- and bimetallic gold and copper on alumina catalysts was prepared and tested in a continuous-flow fixed-bed vertical glass reactor. Among them, $1 \% \mathrm{wt} A \mathrm{Au} / \mathrm{Al}_{2} \mathrm{O}_{3}$ stood out for directing selectivity to acetol $(72 \%)$ at $87 \%$ conversion when adding dihydrogen to the carrier dinitrogen at $300^{\circ} \mathrm{C}$, or towards pyruvaldehyde (sel. $79 \%$ ) at $92 \%$ conversion and $250^{\circ} \mathrm{C}$ if adding dioxygen to dinitrogen. To the best of our knowledge, only a few studies deal with vapor-phase oxidehydration to pyruvaldehyde and generally require higher temperature and catalyst 

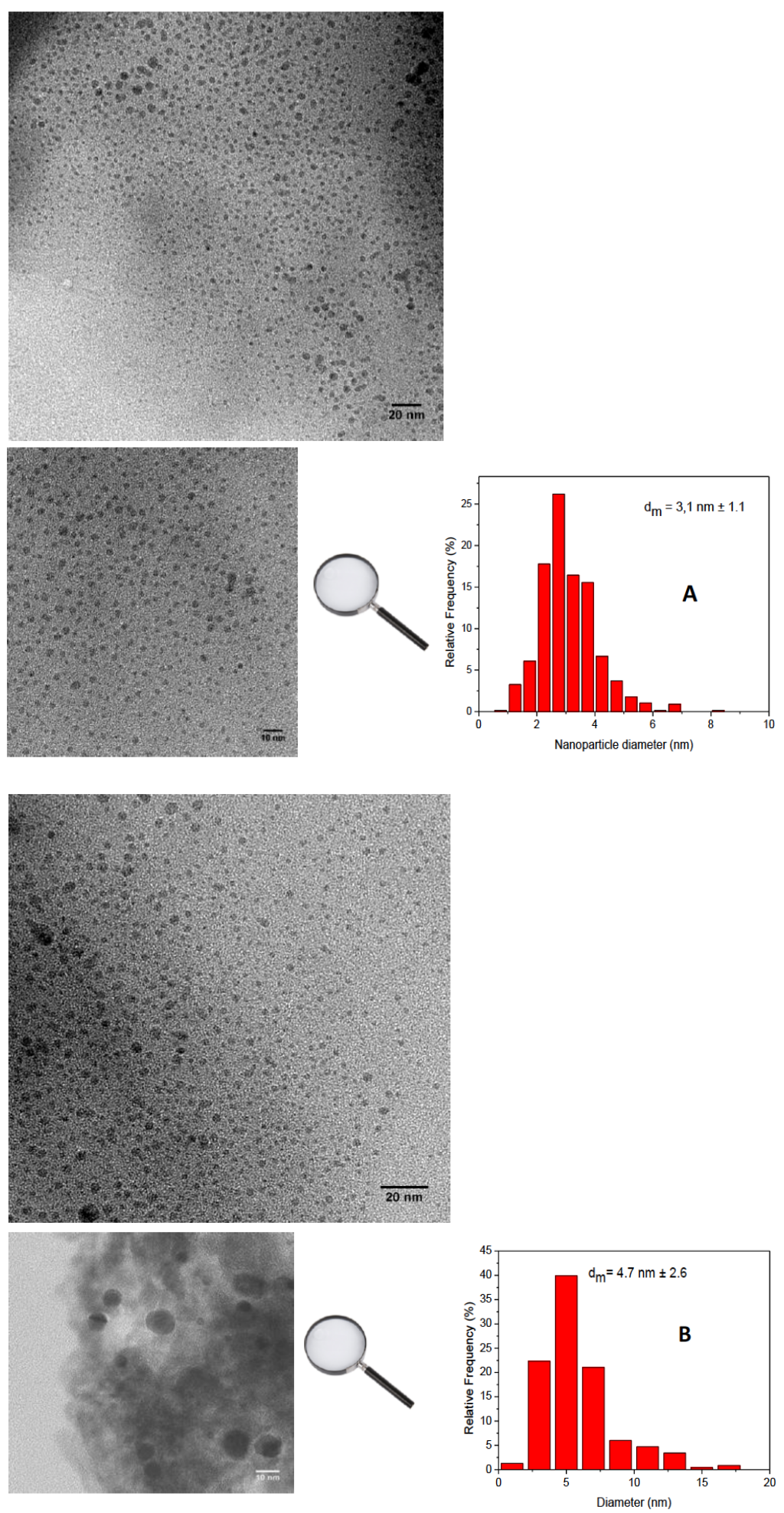

Figure 4: TEM micrographs of $1 \%$ wt $A u / A l_{2} \mathrm{O}_{3} \mathrm{~A}$ ) before the first $9 \mathrm{~h}$-run ('fresh catalyst'); $\mathrm{B}$ ) after the first $9 \mathrm{~h}-\mathrm{run}$ ('used catalyst').

amount. Hence, the present process not only allows for energy savings but also for a good catalyst stability, since it is easily restored after use. Furthermore, the low metal loading in the catalyst and its small amount requested for the tests widely compensate the higher cost for gold with respect to cheaper metals. In conclusion, the reported results may offer a contribute to glycerol valorisation and can stimulate further insight in future studies. 


\section{ACKNOWLEDGEMENTS}

We would like to thank the Università degli Studi Milano for supporting this research by the Piano di Sostegno alla Ricerca 2019 PSR2019_DIP_005_PI_LCARL

\section{REFERENCES}

[1] Pagliaro M, Rossi M. The future of glycerol. 2nd ed. RSC Green Chemistry Series. RSC Publishing; 2010

[2] International Renewable Energy Agency. Boosting Biofuels. Sustainable Paths to Greater Energy Security; IRENA, 2016.

[3] Pagliaro M, Ciriminna R, Kimura H, Rossi M, Della Pina C. From glycerol to value-added products. Angew. Chem. Int. Ed 2007; 46: 4434-4440. https://doi.org/10.1002/anie.200604694

[4] Pagliaro M, Rossi M, Della Pina C, Ciriminna R, Kimura H. Recent advances in the conversion of bioglycerol into valueadded products. Eur. J. Lipid Sci. Technol 2009; 111: 788799.

https://doi.org/10.1002/ejlt.200800210

[5] Skrzyńska E, Wondołowska-Grabowska A, Capron M, Dumeignil $F$. Crude glycerol as a raw material for the liquid phase oxidation reaction. Appl. Catal. A 2014; 482: 245-257. https://doi.org/10.1016/j.apcata.2014.06.005

[6] Gholami Z, Abdullah AZ, Lee KT. Dealing with the surplus of glycerol production from biodiesel industry through catalytic upgrading to polyglycerols and other value-added products. Renew. Sustain. Energy Rev 2014; 39: 327-341. https://doi.org/10.1016/j.rser.2014.07.092

[7] Villa A, Dimitratos N, Chan-Thaw CE, Hammond C, Prati L, Hutchings GJ. Glycerol oxidation using gold-containing catalysts. Acc. Chem. Res 2015; 48: 1403-1412. https://doi.org/10.1021/ar500426g

[8] Dodekatos $G$, Schünemann $S$, Tüysüz H. Recent advances in thermo-, photo-, and electrocatalytic glycerol oxidation. ACS Catal 2018; 8: 6301-6333. https://doi.org/10.1021/acscatal.8b01317

[9] Katryniok B, Paul S, Capron M, Dumeignil F. Towards the sustainable production of acrolein by glycerol dehydration. Chem. Sus. Chem 2009; 2: 719-730. https://doi.org/10.1002/cssc.200900134

[10] Katryniok B, Paul S, Dumeignil F. Recent developments in the field of catalytic dehydration of glycerol to acrolein. ACS Catal 2013; 3: 1819-1834 https://doi.org/10.1021/cs400354p

[11] Sun D, Yamada Y, Sato S, Ueda W. Glycerol as a potential renewable raw material for acrylic acid production. Green
Chem 2017; 19: 3186-3213

https://doi.org/10.1039/C7GC00358G

[12] Smith LR, Sainna MA, Douthwaite M, Davies TE, Dummer NF, Willock DJ, Knight DW, Catlow CRA, Taylor SH, Hutchings GJ. Gas phase glycerol valorization over ceria nanostructures with well-defined morphologies. ACS Catal 2021; 11: 4893-4907. https://doi.org/10.1021/acscatal.0c05606

[13] Smith LR, Smith PJ, Mugford KS, Douthwaite M, Dummer NF, Willock DJ, Howard M, Knight DW, Taylor SH, Hutchings GJ. New insights for the valorisation of glycerol over $\mathrm{MgO}$ catalysts in the gas-phase. Catal. Sci. Technol 2019; 9: 1464-1475.

https://doi.org/10.1039/C8CY02214C

[14] Lopez-Pedrajas S, Estevez R, Schnee J, Gaigneaux EM Luna D, Bautista F.M. Study of the gas-phase glycerol oxidehydration on systems based on transition metals (Co, $\mathrm{Fe}, \mathrm{V}$ ) and aluminium phosphate. Mol. Catal 2018; 455: 6877. https://doi.org/10.1016/j.mcat.2018.05.020

[15] Mohamad MH, Awang R, Yunus WMZW. A Review of Acetol: Application and Production. Am. J. Applied Sci 2011; 8: 1135-1139.

https://doi.org/10.3844/ajassp.2011.1135.1139

[16] Drumright RE, Gruber PR, Henton DE. Polylactic acid technology. Adv. Mater 2000; 12: 1841-1846. https://doi.org/10.1002/1521-4095(200012)12:23<1841::AIDADMA1841>3.0.CO;2-E

[17] Baltes H, Leupold El, US Pat, 4302609, 1981.

[18] Lari GM, García-Muelas R, Mondelli C, López N, PérezRamírez J. Glycerol oxidehydration to pyruvaldehyde over silver-based catalysts for improved lactic acid production. Green. Chem 2016; 18: 4682-4692. https://doi.org/10.1039/C6GC00894A

[19] Bond GC, Louis C, Thompson DT. Catalysis by Gold. Catalytic Science Series, vol. 6, Imperial College Press, Singapore, 2006, p. 89. https://doi.org/10.1142/p450

[20] Della Pina C, Falletta E, Rossi M. Highly selective oxidation of benzyl alcohol to benzaldehyde catalyzed by bimetallic gold-copper catalyst. J. Catal 2008; 260: 384-386. https://doi.org/10.1016/j.jcat.2008.10.003

[21] Della Pina C, Falletta E, Rossi. Update on: selective oxidation using gold. Chem. Soc. Rev 2012; 41: 350-369. https://doi.org/10.1039/C1CS15089H

[22] Falletta E, Della Pina C, Rossi M, He Q, Kiely CJ, Hutchings GJ. Enhanced performance of the catalytic conversion of allyl alcohol to 3-hydroxypropionic acid using bimetallic gold catalysts. Faraday Discuss 2011; 152: 367-379. https://doi.org/10.1039/c1fd00063b 